\title{
IMPLEMENTASI TEKNIK HEURISTIC DAN PEMODELAN POHON KEPUTUSAN TERHADAP PERANCANGAN GAME IQ
}

\author{
Romindo \\ Manajemen Informatika, Politeknik Ganesha Medan \\ Email: romindo4@gmail.com
}

\begin{abstract}
ABSTRAK
Banyaknya pilihan-pilihan yang ada dalam melakukan pencarian dapat menjadi sebuah permasalahan baru, hal ini membutuhkan waktu yang lama dalam melakukan pencarian. Salah satu teknik yang dibutuhkan dalam penyelesaian masalah tersebut adalah Teknik Heuristic. Teknik Heuristic adalah sebuah teknik yang mengembangkan efisiensi dalam proses pencarian yang disebut sebagai fungsi heuristic. Pengambilan keputusan yang mungkin dari semua alternatif yang ada dapat dilakukan dengan pemodelan pohon keputusan (Decision Tree). Hampir semua permainan (game) yang berjenis strategi seperti game IQ dirancang dengan pemodelan pohon keputusan karena setiap cabang pada pohon merepresentasikan keputusan yang mengawali penyelesaian yang lebih komplit dan node daun merepresentasikan penyelesaian yang komplit. Game Intelligence Quotient (IQ) merupakan permainan yang kerap digunakan untuk mengukur kecerdasan intelektual dan kemampuan seseorang dalam memahami gagasan, memecahkan masalah, mempelajari berbagai hal, hingga berpikir dan bernalar. Sehingga perancangan game IQ membutuhkan teknik heuristic dan pemodelan pohon keputusan, untuk menemukan solusi terbaik dengan menggunakan metode pencarian Minimax Searching.
\end{abstract}

Kata Kunci: Teknik Heuristic, Decision Tree, Game IQ

\section{PENDAHULUAN}

\subsection{Latar Belakang}

Banyak persoalan rumit dapat dibuat pemodelannya dengan menggunakan Decision Tree (pohon keputusan), dimana setiap node dari pohon (tree) merepresentasikan langkah dari penyelesaian permasalahan.

Pengambilan suatu keputusan dalam menyelesaikan suatu persoalan rumit dapat dilakukan dengan membuat suatu pemodelan. Dari pemodelan inilah akan didapatkan suatu teknik yang akan menyelesaikan persoalan rumit tersebut. Dalam hal ini, pemodelan yang digunakan adalah pemodelan dengan Pohon Keputusan dan teknik yang dipakai adalah teknik Heuristic. (Romindo, Analisa Perbandingan Metode ANP dan SAW Dalam Menentukan Mahasiswa Terbaik, 2019)

Beberapa permainan strategi atau permainan yang mengasah otak dapat dibentuk pemodelannya dengan menggunakan pohon keputusan dengan teknik - teknik penyelesaiannya.

Pohon keputusan adalah salah satu metode klasifikasi yang paling populer karena mudah untuk di interpretasi oleh manusia. Pohon keputusan adalah model prediksi menggunakan struktur pohon atau struktur berhirarki. Konsep dari pohon keputusan adalah mengubah data menjadi pohon keputusan dan aturan - aturan keputusan. Manfaat utama dari penggunaan pohon keputusan adalah kemampuannya untuk mem-break down proses pengambilan keputusan yang kompleks menjadi lebih simple sehingga pengambilan keputusan akan lebih menginterpretasikan solusi dari permasalahan. Pohon keputusan juga berguna untuk mengeksplorasi data, menemukan hubungan tersembunyi antara sejumlah calon variabel input dengan sebuah variabel target (Andriani, 2013).

Teknik Pencarian Heuristic merupakan suatu strategi untuk melakukan proses pencarian ruang keadaan (state space) suatu problema secara selektif yang memandu proses pencarian yang kita lakukan disepanjang jalur yang memiliki kemungkinan sukses paling besar dan mengesampingkan usaha yang bodoh dan memboroskan waktu. Heuristic adalah sebuah teknik yang mengembangkan efisiensi dalam proses pencarian, namun dengan kemungkinan mengorbankan kelengkapaan.

Untuk dapat menerapkan heuristic tersebut dengan baik dalam suatu domain tertentu diperlukan suatu Fungsi Heuristic. Fungsi Heuristic ini digunakan untuk mengevaluasi keadaan - keadaan problema individual dan menentukan seberapa jauh hal tersebut dapat digunakan untuk mendapatkan solusi yang di inginkan.

Berdasarkan penjelasan diatas, maka dicoba untuk melakukan Perancangan Perangkat Lunak Permainan Asah Otak Dengan Pemodelan Pohon Keputusan dan Teknik Pencarian Heuristic dalam menemukan langkah - langkah terbaik untuk menyelesaikan permainan tersebut.

\subsection{Tinjuan Pustaka}

1. Pohon / Tree

Dalam kehidupan sehari-hari banyak sekali ditemukan persoalan yang bila digambarkan dengan suatu diagram akan terbentuk sebuah pohon atau tree secara umum. Secara sederhana struktur data pohon dapat didefinisikan sebagai kumpulan elemen-elemen yang mana salah satu dari elemen tersebut merupakan akar bagi elemen yang lain. 
Dan elemen yang tersisa adalah simpul yang nantinya akan terpecah lagi menjadi sejumlah simpul lain yang tidak berhubungan antara satu dengan lainnya. Simpul tersebut dikatakan cabang (branch) dari suatu pohon. Tapi masing-masing cabang tersebut akan selalu berhubungan dengan simpul yang diatasnya. Seperti layaknya hubungan antara orangtua dan anak (Suyanto, 2017). Agar lebih jelasnya lagi dapat digambarkan suatu struktur pohon sembarang sebagai berikut :

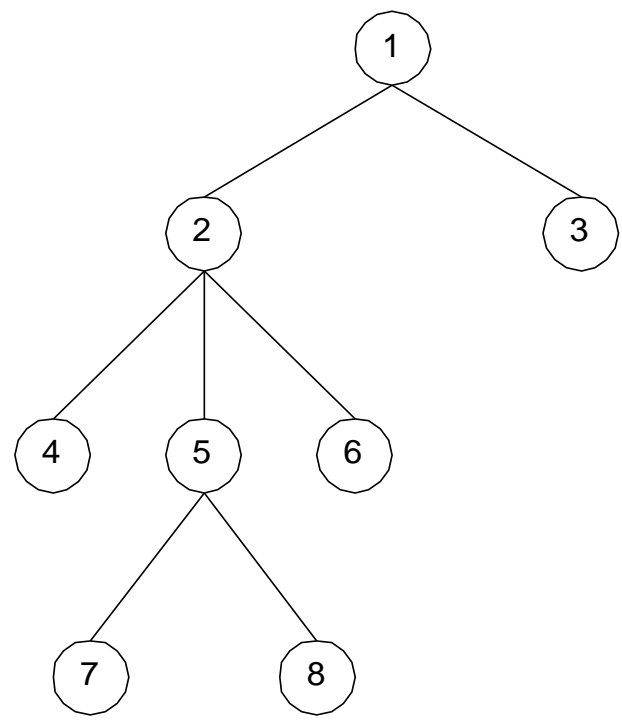

Gambar 1. Struktur pohon sembarang.

Banyak contoh yang menggambarkan pohon tersebut, yang mana menjelaskan kepada user tentang hubungan logic antar data dalam bentuk hubungan bertingkat (hierarki).

2. Pemodelan Decision Tree (pohon keputusan) pada Game $I Q$.

Pohon keputusan (decision tree) adalah sejenis struktur pohon yang menggambarkan solusi atau semua kemungkinan situasi pengambilan keputusan dari suatu persoalan (Azmi \& Dahria, 2013).

Untuk menemukan solusi yang optimum, hanya perlu dilakukan penelurusan tree (pohon) untuk mencari node pada pohon yang sesuai dengan kriteria yang diinginkan (dimaksud).

Pohon keputusan ini banyak digunakan dalam merancang suatu permainan, terutama permainan jenis strategi. Karena dalam permainan jenis strategi ini seorang pemain akan dihadapkan pada banyak kemungkinan dalam hal pengambilan keputusan. Sebagai contoh dalam permainan Catur Jawa, jika seorang pemain menjalankan satu langkah, ada lebih dari satu kemungkinan yang akan dihadapi oleh pemain tersebut. Jika yang berhadapan dengan pemain adalah komputer maka komputer akan melakukan proses pencarian terhadap pohon keputusan untuk menemukan langkah yang paling tepat untuk menghadapi langkah pemain tersebut.

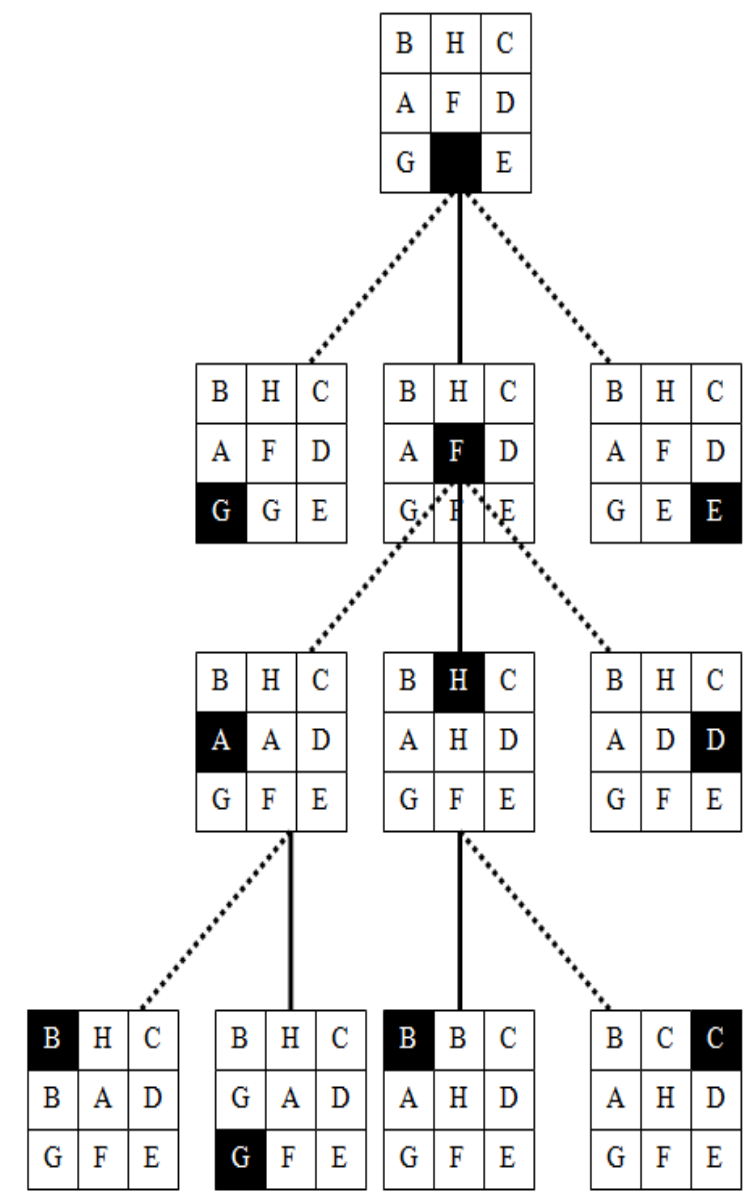

Gambar 2. Pemodelan Decision Tree pada Game IQ.

\subsection{Penelitian Terdahulu}

Sebagai referensi dalam penelitian ini, maka diperlukan beberapa penelitian terdahulu yang pernah dilakukan. Diantaranya yaitu:

Penelitian yang lakukan oleh (Romindo, Analisa Perbandingan Metode ANP dan SAW Dalam Menentukan Mahasiswa Terbaik, 2019) "Analisa Perbandingan Metode ANP dan SAW Dalam Menentukan Mahasiswa Terbaik" yang membahas tentang proses pemilihan mahasiswa terbaik yang melibatkan banyak komponen atau kriteria yang dinilai (multikriteria), sehingga dalam penyelesaiannya diperlukan sebuah sistem pendukung keputusan dengan multikriteria. Diantara metode ANP dan SWA pada sistem pendukung keputusan, maka dibutuhkan metode mana yang terbaik dalam menentukan mahasiswa terbaik di Politeknik Ganesha Medan.

Penelitian yang dilakukan oleh (Sonata, 2018) dengan judul "Analisis Studi Kelayakan Pelayanan E-Commerce Menggunakan Metode Analytical Hierarchy Process (AHP)". Penelitian ini 
membahas tentang penerapan metode AHP pada sistem pendukung keputusan yang digunakan untuk mengolah dan menganalisa jenis $e$-commerce yang layak direkomendasikan untuk konsumen di Indonesia.

Penelitian yang dilakukan oleh (Mardiana, Zalilludin, \& Fitriani, 2020). Penelitian ini membahas tentang sistem pendukung keputusan dengan menggunakan fuzzy Tsukamoto untuk membantu dan meningkatkan kinerja proses pemilihan siapa yang berhak mendapatkan bantuan pemerintah. Hasil ini, menghasilkan sistem pendukung keputusan dan daftar keluarga miskin yang layak dan tidak layak mendapatkan bantuan pemerintah.

Penelitian yang dilakukan oleh (Prasetyo \& Kusumah, 2015) dengan judul Sistem Pendukung Keputusan Mahasiswa Berprestasi Menggunakan Metode Analytical Hierarchy Process (AHP) (studi kasus: universitas majalengka). Penelitian ini membahas tentang proses pengambilan keputusan untuk menyelesaikan masalah menjadi beberapa bagian. Sistem Pendukung Keputusan merancang Seleksi Berprestasi Mahasiswa menggunakan metodologi pengembangan sistem Extreme Programming dan pemodelan UML.

Penelitian terdahulu yang dilakukan oleh (Romindo, 2020) yang berjudul Implementasi Metode SAW Terhadap Sistem Pendukung Keputusan Memilih Dosen Terbaik Pada Politeknik Ganesha. Penelitian ini membahas tentang proses pemilihan dosen terbaik memberikan pengakuan bagi dosen yang mengusungnya dari kegiatan Tridharma Perguruan Tinggi yang hasilnya bisa dibanggakan dan bermanfaat untuk memajukan kualitas akademik dan kelembagaan. Institusi pendidikan, khususnya Politeknik Ganesha Medan setiap tahun menyeleksi dosen terbaik dengan memilihnya penilaian dengan membagikan kuesioner kepada siswa.

\section{METODOLOGI PENELITIAN}

\subsection{Metode Pengumpulan Data}

Pada metode pengumpulan data untuk mendapatkan data yang cukup akurat, maka digunakan beberapa metode di bawah ini yaitu :

\section{Studi pustaka}

Dengan metode pengambilan data secara umum, didapat data-data yang diambil dari bermacammacam buku, literatur, dan referensi. Sehingga data-data yang diambil dapat mendukung dan melengkapi untuk membantu dalam melakukan penelitian.

2. Eksperimen

Setelah mendapatkan data secara studi pustaka, proses penelitian akan dilakukan eksperimen atau percobaan. Dalam eksperimen ini pengumpulan data dapat diambil secara langsung, sehingga akan lebih mendalami dalam melakukan penelitian. Peneliti juga melakukan percobaan berulang-ulang untuk menghindari dan meminimalkan kesalahan dalam penelitian ini.

\subsection{Pembangunan Sistem}

Proses pembangunan game ini dilakukan melalui beberapa tahap, yaitu:

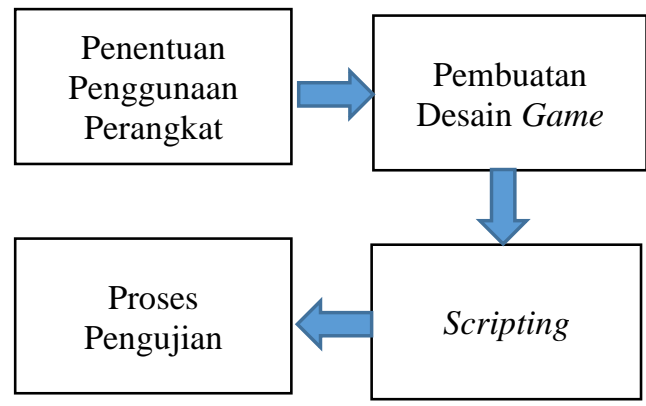

Gambar 3. Pembangunan Sistem

\subsection{Perancangan Antarmuka}

Perancangan antarmuka dititikberatkan pada ketepatan sasaran pilihan menu. Adapun gambaran umum untuk rancangan menu dengan flowchart.

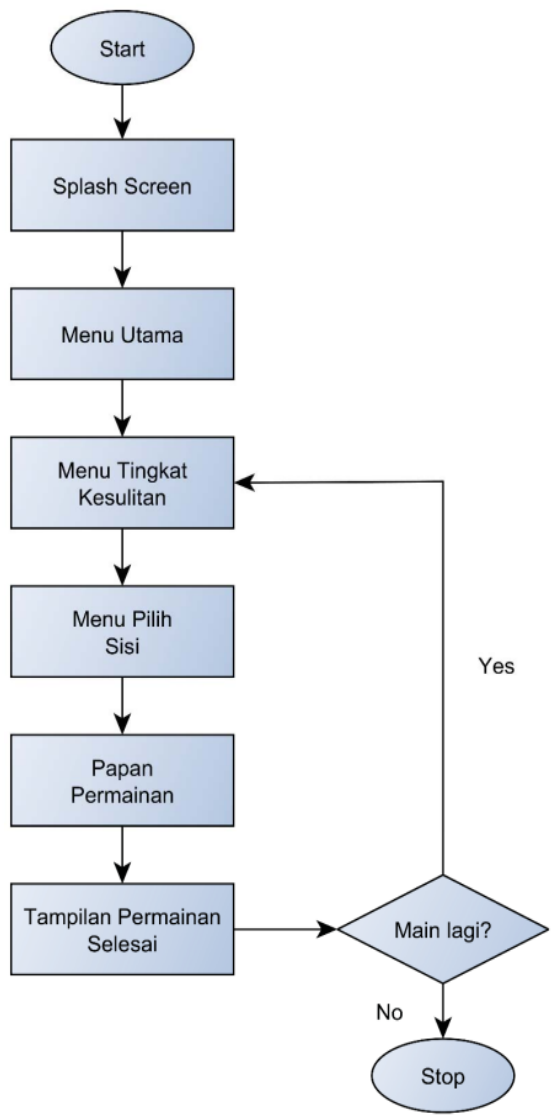

\section{Gambar 4. Flowchart rancangan menu aplikasi}

Saat aplikasi dijalankan, tampilan Splash Screen akan muncul sesaat, kemudian Menu Utama akan muncul. 


\section{HASIL DAN PEMBAHASAN}

Mengapa disebut Game IQ ? Permainan yang dirancang ini disebut Game IQ karena dalam permainan ini dibutuhkan proses penalaran dan cara berfikir manusia (pemain) dengan cara simulasi atau berlatih untuk memecahkan masalah dalam hal ini adalah permainan Game IQ ini. Game IQ ini merupakan salah satu permainan puzzle asah otak dimana pemain dituntut untuk menyelesaikan puzzle dalam waktu sesingkat mungkin. Teknik yang mendasar agar manusia (pemain) dapat melakukan penalaran dan cara berfikir yang baik adalah dengan teknik kecerdasan buatan. Teknik kecerdasan buatan teridiri atas 3 bagian penting yaitu : Pencarian (Search), Representasi pengetahuan / penggunaan ilmu pengetahuan dan Abstraksi Permainan. Salah satu bagian penting dalam teknik kecerdasan buatan adalah pencarian (search). Pencarian yang diterapkan dalam Game IQ ini adalah pencarian teknik heuristic.

Game IQ ini merupakan sebuah papan permainan yang berbentuk bingkai dengan ukuran 4 kali 5 yang didalamnya terdapat dua puluh kotak yang diberi angka 1 s/d 19 dengan menyisakan satu tempat kosong untuk memulai permainan. Permainan dimulai dengan menuliskan nama pemain kemudian menekan tombol F2 (New Game) atau klik menu File - New Game lalu komputer akan membuat susunan angka - angka yang semula tersusun secara terurut menjadi teracak, sehingga untuk memulai permainan pemain perlu menggeser kotak - kotak angka yang ada dalam papan permainan tersebut. Pergeseran dapat dilakukan ke kiri, kanan, atas dan bawah dengan memperhatikan langkah dan waktu untuk mencapai posisi akhir. Berikut diperlihatkan dalam gambar 5. bentuk penyajian kotak - kotak permainan :

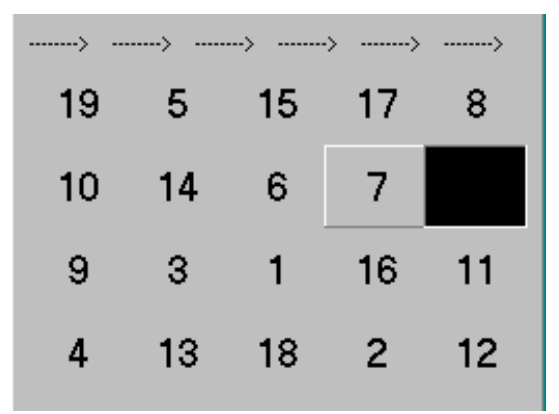

Gambar 5. Papan permainan Game IQ.

Umumnya, para user memecahkan masalah permainan dengan cara coba - coba dan tentu saja menimbulkan banyak kesalahan dan mungkin dilakukan secara terus menerus, sehingga menghasilkan kesalahan pada saat memulai dan kemudian buntu sebelum kemenangan dapat dicapai. Biasanya pada saat memulai, pemain akan dihadapkan pada satu situasi, dimana satu posisi permainan harus dipilih dan posisi tersebut nantinya akan sangat berpengaruh pada posisi permainan selanjutnya.

\subsection{Metode Pencarian}

Suatu metode yang paling mendasar untuk membantu pemecahan masalah adalah metode pencarian (search). Tetapi ada kalanya metode search ini terlalu lama dalam melakukan pencarian dalam memecahkan suatu masalah, untuk itu metode search tersebut dikembangkan lagi menjadi suatu metode yang disebut dengan metode Heuristic.

Untuk mengimplementasikan metode Heuristic pada permainan Game IQ, akan dilakukan dengan metode yang standard yaitu dengan menggunakan suatu posisi awal dan menghasilkan suatu posisi akhir.

\begin{tabular}{|c|c|c|c|c|}
\hline 1 & 2 & 3 & 4 & 5 \\
\hline 6 & 7 & 8 & 9 & 10 \\
\hline 11 & 12 & 13 & 14 & 15 \\
\hline 16 & 17 & 18 & 19 & \\
\hline
\end{tabular}

(1)

\begin{tabular}{|c|c|c|c|c|}
\hline & 1 & 2 & 3 & 4 \\
\hline 5 & 6 & 7 & 8 & 9 \\
\hline 10 & 11 & 12 & 13 & 14 \\
\hline 15 & 16 & 17 & 18 & 19 \\
\hline
\end{tabular}

(2)

\section{Gambar 6. Posisi akhir yang mungkin dilakukan pada game IQ.}

Secara garis besar pergeseran yang dapat dilakukan pada Puzzle diatas dapat dilihat sebagai berikut : pada posisi awal pemain dihadapkan pada 3 posisi yang mungkin dapat dilakukan yaitu 6 di geser ke bawah, 7 di geser ke kanan atau 5 digeser ke kiri, karena yang diharapkan adalah mencapai posisi akhir secepat mungkin maka pergeseran dilakukan diatas pada posisi (1), sehingga 6 bergeser kebawah, pada posisi (2) 8 juga digeser kebawah sehingga posisi kosong tepat berada di kanan 2, pada posisi (3) 2 digeser ke kanan untuk memberikan tempat kepada 1 untuk bergeser keatas, sehingga pada posisi (4) sudah kelihatan posisi akhir sudah hampir dicapai dan seterusnya hingga tercapai posisi akhir yaitu : 1,2,3,4,5,6,7,8.

\subsection{Analisis Masalah}

Penulis akan membahas mengenai analisis permasalahan yang terkait dengan kasus yang diangkat sebagai permasalahan yakni penerapan algoritma depth-first search dalam penyelesaian permainan edukasi yaitu permainan puzzle untuk 
menyusun angka-angka yang teracak menjadi susunan angka yang tepat dan berurutan. Analisis masalah sangatlah penting dalam suatu penelitian karena pada tahapan ini merupakan salah satu proses mengidentifikasi masalah-masalah yang timbul dari penerapan system yang akan penulis teliti yaitu mengenai algoritma depth-first dalam penyelesaian permainan edukasi yaitu permainan puzzle mengenai bagaimana teknik yang digunakan serta aturan dalam penerapan algoritma depth-first search.

Seperti telah dijelaskan sebelumnya bahwa teknik algoritma yang digunakan dalam penyelesaian game puzzle Angka adalah algoritma depth-first search.

Adapun kebutuhan aturan-aturan yang harus dipenuhi dalam menjalankan game puzzle angka ini, antara lain sebagai berikut :

1. Aturan-aturan yang terdapat pada game puzzle angka :

a. Arah perpindahan kotak kosong (blank tile) harus secara vertikal atau horizontal atau tidak diperbolehkan diagonal atau melengkung.

b. Kotak-kotak yang terdapat pada suatu game adalah saling merapat dan tidak berpotongan terisi penuh oleh angka kecuali satu kotak kosong untuk perpindahan angka puzzle.

c. Solusi pada game puzzle angka adalah semua angka yang terdapat pada kotak tersusun dengan benar dari angka yang paling rendah yaitu 1 pada atas sebelah kiri sampai dengan angka yang paling tinggi yaitu 15 pada sebelah kanan bawah.

\subsection{Analisis Algoritma}

Analisis Algoritma merupakan salah satu metode/alat yang digunakan untuk membantu proses penyelesaian game puzzle dengan lebih mudah, proses penyelesaian game puzzle angka yang penulis gunakan antara lain, algoritma depthfirst search.

\subsection{Algoritma Depth First Search}

Cara kerja algoritma Depth-First Search. Misalkan terdapat tiga kotak 1, 2, 3 pada sebuah papan. Sebuah kotak dapat dipindahkan jika tidak ada kotak lain di atasnya dan hanya ada satu kotak yang nantinya boleh dipindahkan. Ada dua kemungkinan pemindahannya, antara lain:

1. Pindahkan sebuah kotak ke atas papan.

2. Pindahkan sebuah kotak ke atas kotak lainnya.

Masalah muncul jika diketahui keadaan awalnya (initial state atau current state) dan tujuan akhirnya (goal state atau final state). Seperti pada gambar berikut :

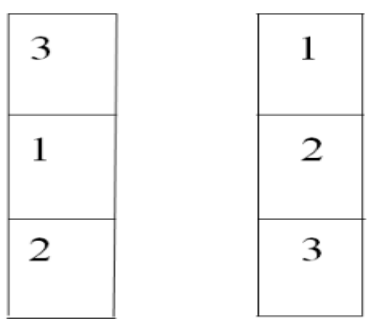

Susunan Awal Susunan Akhir

\section{Gambar 7. Contoh permainan yang menerapkan pencarian.}

Pada gambar 7 dapat dilihat bahwa ruang keadaan tersebut memiliki 13 elemen atau node, dengan perpindahan sebagai berikut:

1. Perpindahan kotak 1 ke atas papan untuk lintasan d dan e.

2. Perpindahan kotak 3 ke atas papan untuk lintasan a.

3. Perpindahan kotak 1 ke atas kotak 2 untuk lintasan 1.

4. Perpindahan kotak 1 ke atas kotak 3 untuk lintasan $b$ dan $m$.

5. Perpindahan kotak 2 ke atas kotak 1 untuk lintasan c dan g.

6. Perpindahan kotak 2 ke atas kotak 3 untuk lintasan i dan j.

7. Perpindahan kotak 3 ke atas kotak 1 untuk lintasan $\mathrm{h}$.

8. Perpindahan kotak 3 ke atas kotak 2 untuk lintasan $\mathrm{f}$ dan $\mathrm{k}$.

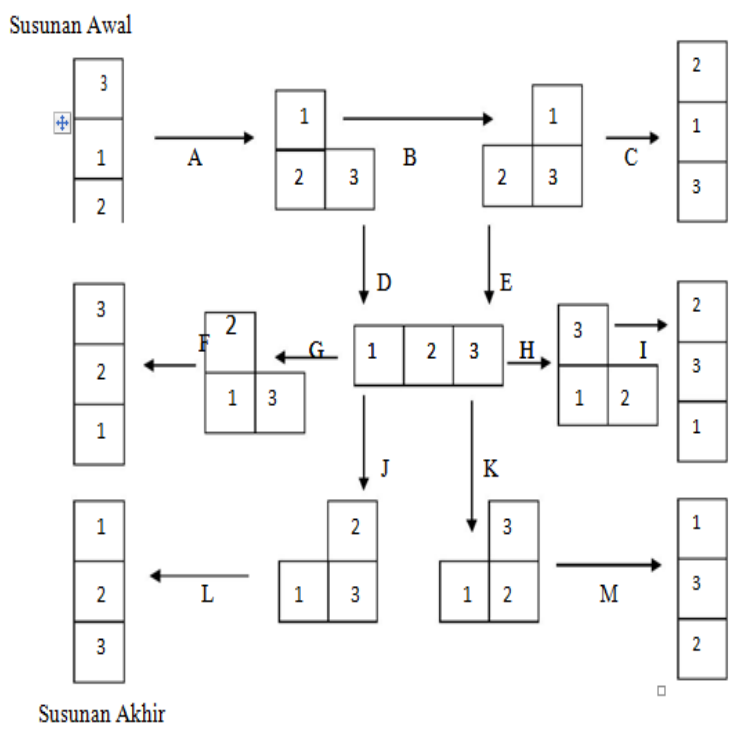

Gambar 8. Penyelesaian Depth First Search.

Penyelesaian untuk masalah permainan pada gambar 8 adalah anggota kumpulan semua lintasan dari keadaan awal hingga tujuan yang lintasannya ditandai dengan huruf A, D, J, dan L. Yaitu mulai dari A pada susunan acak samapai dengan susuna $\mathrm{L}$ pada saat telah tersusun dengan benar, dengan artian bahwa lintasan yang benar hingga angka menjadi tersusun yaitu melintasi lintasan $\mathrm{A}, \mathrm{D}, \mathrm{J}$ dan 
L dan lintasan-lintasan lainnya merupakan lintasan yang tidak menemukan goal state atau tujuan.

\subsection{Algoritma Depth First Search}

Dalam perancangan permainan ini terdapat lima buah form, antara lain : form pertama adalah : form board, yaitu form yang terdiri atas objek TSpeedbutton, objek Tpanel, objek TTimer, objek Tedit dan tombol lainnya. Tampilan aplikasi form yang pertama adalah :

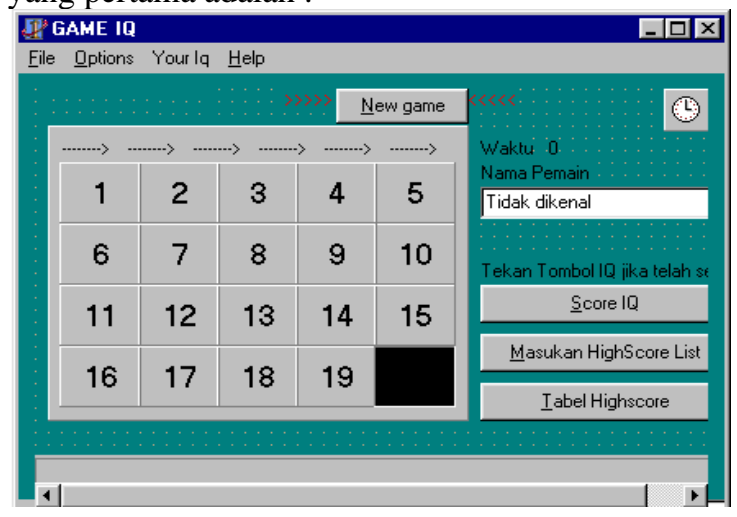

Gambar 9. Tampilan form board game IQ.

Form yang kedua adalah form Highscore List yang terdiri atas objek : Tmemo dan Tbutton. Form yang ketiga adalah form Help yang terdiri atas objek : Tpanel, Tbutton, Tlabel. Form yang keempat adalah form About yang terdiri atas objek : GroupBox, Tpanel, Ttimer, Tlabel, dan tombol lainnya.

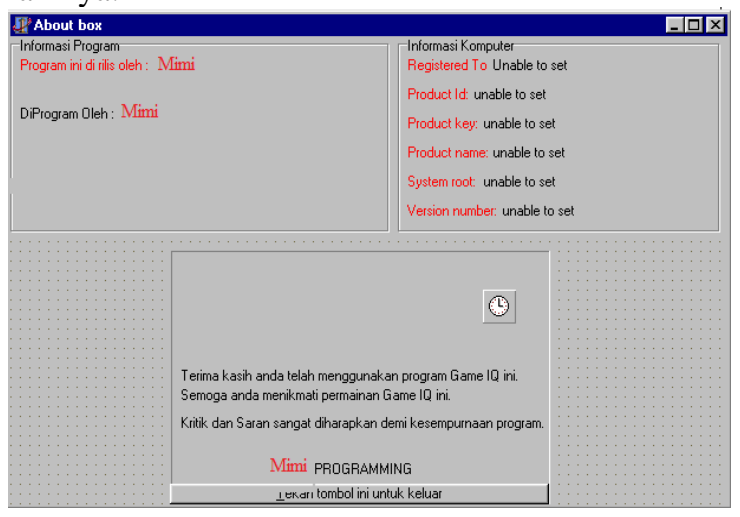

Gambar 10. Tampilan About Box

\section{KESIMPULAN}

Dari hasil dan pembahasan yang dilakukan, dapat diambil kesimpulan sebagai berikut :

1. Merancang sebuah permainan IQ yang digunakan untuk mengukur kecerdasan intelektual dan kemampuan seseorang dalam memahami gagasan, memecahkan masalah, mempelajari berbagai hal, hingga berpikir dan bernalar pada manusia.

2. Penerapan teknik heuristic dan pemodelan pohon keputusan dalam merancang game IQ yang memudahkan atau efisiensi terhadap proses pencarian diantara pilihan-pilihan yang ada.

\section{PUSTAKA}

Andriani, A. (2013). Sistem Pendukung Keputusan Berbasis Decision Tree Dalam Pemberian Beasiswa Studi Kasus: AMIK "BSI Yogyakarta". Seminar Nasional Teknologi Informasi dan Komunikasi 2013 (SENTIKA 2013) (pp. 163-168). Yogyakarta: SENTIKA.

Azmi, Z., \& Dahria, M. (2013). Decision Tree Berbasis Algoritma Untuk Pengambilan Keputusan. Jurnal SAINTIKOM, 157-164.

Mardiana, A., Zalilludin, D., \& Fitriani, D. (2020). Sistem Pendukung Keputusan Penentuan Keluarga Miskin Menggunakan Logika Fuzzy Tsukamoto. Infotech Journal, 2429.

Prasetyo, T. F., \& Kusumah, C. (2015). Sistem Pendukung Keputusan Mahasiswa Berprestasi Menggunakan Metode Analytical Hierarchy Process (AHP) (Studi Kasus: Unversitas Majalengka). Jurnal J-Ensitec, 47-53.

Romindo, R. (2019). Analisa Perbandingan Metode ANP dan SAW Dalam Menentukan Mahasiswa Terbaik. Jurnal Mantik Penusa, 43-50.

Romindo, R. (2020). Implementasi Metode SAW Terhadap Sistem Pendukung Keputusan Memilih Dosen Terbaik Pada Politeknik Genesha Medan. Riset dan E-Jurnal Manajemen Informatika Komputer, 90-95.

Sonata, F. (2018). Analisis Studi Kelayakan Pelayanan E-Commerce Menggunakan Metode Analytical Hierarchy Process (AHP). Jurnal Komunikasi, Media dan Informatika, 58-71.

Suyanto, S. (2017). Searching, Reasoning, Planning Dan Learning. Bandung: Informatika. 